\section{A letter from Canada's new minister of health}

Thank you for your editorial on my new role as the federal minister of health. ${ }^{1}$ Throughout my career, I have been guided by the triple aim of providing better care and better health outcomes for my patients while ensuring the best value for our health care investments. Now, as the federal minister of health, I have the privilege to advance these goals for all Canadians.

I assure you that this is not a privilege I take lightly. Our government has an ambitious health agenda - one for which I am accountable. At its centre is the need to strengthen and modernize our publicly funded universal health care system to ensure it meets the challenges of the future. This includes upholding the principles of the Canada Health Act, particularly that of access to care based on need and not the ability to pay.

As a physician, I know that patients and providers experience first-hand many of the problems in our health care system. In the same way new treatments and technology have helped our patients achieve better outcomes, we need a new approach to the health care system itself. Home care, affordable prescription drugs, mental health and innovation are key priorities that we will address. A renewed partnership between the federal government and provinces and territories is essential to achieving this.

I have already had the opportunity to speak with my provincial and territorial counterparts, and I will be meeting with them soon to begin the development of a new multiyear health accord.

I have also initiated discussions with indigenous leaders to understand the health priorities and unique concerns of their communities. We are fully committed to renewing our nation-to-nation relationship with indigenous peoples.

We are interested not only in improving the health system, but also in helping Canadians be healthier. For example, my mandate letter from the prime minister commits to such important public health initiatives as increasing vaccination rates, regulating trans fats and salt in processed food, improving information about sugar on food labels, and changing tobacco packaging.

Your editorial asked me to confront the social determinants of health. I am proud to say that the entire agenda of our government is designed to respond to the root causes of health inequities - including support for affordable housing, investing in public infrastructure and creating jobs.

We have also committed to making decisions guided by science and the best available evidence.

I am truly honoured to serve as the federal minister of health. It is my hope that together we can create a stronger, publicly funded health care system for all Canadians. In fulfilling my mandate, I will uphold the values that inform us as physicians - including empathy, compassion, integrity and a relentless pursuit of health for all.

\section{The Honourable Jane Philpott MD} Federal Minister of Health, Ottawa, Ont.

\section{Reference}

1. Stanbrook MB, Flegel K, Kelsall D, et al. A letter to our colleague, Canada's new minister of health. CMAJ 2016;188:9.

CMAJ 2016. DOI:10.1503/cmaj.1150078

\section{Spontaneous rib fracture: consider other neoplastic causes}

I read with interest $C M A J$ 's Decisions article describing a spontaneous rib fracture in a 66-year-old woman with a long-standing history of osteopenia. ${ }^{1}$

I venture that, in addition to breast cancer, careful consideration for the differential diagnosis should be given to possible bone cancer, specifically, multiple myeloma. Although multiple myeloma is more common in patients that are male and of certain ethnicities, the median age of onset is 66 years, and the rib fracture may represent a plasmacytoma: a proliferation of plasma cells distant from the primary of multiple myeloma. ${ }^{2}$

In a patient with long-standing osteopenia, it would be easy to miss multiple myeloma or another primary bone neoplasm, but it almost certainly needs to be ruled out with a complete assessment and appropriate testing as required (key among these being a complete blood count with a peripheral smear, serum protein electrophoresis for a specific diagnosis of multiple myeloma, and a skeletal survey with plain films and/or a bone scan to identify a primary site).

Thank you for sharing this most interesting case.

\section{Lawrence C. Loh MD MPH}

Adjunct Professor, Dalla Lana School of Public Health, University of Toronto, Toronto, Ont.

\section{References}

1. Harris SR. A 66-year-old woman with spontaneous rib fracture. CMAJ 2015;187:988-9.

2. Loh LC, Rao RV, Ng D. Uncommon, sinister vertebral fracture: early-onset multiple myeloma. Can Fam Physician 2013;59:1195-9.

CMAJ 2016. DOI:10.1503/cmaj.1150079

\section{Letters to the editor}

In submitting a letter, you automatically consent to having it appear online/in print. All letters accepted for print will be edited for space and style. See www.cmaj.ca for full versions and competing interests. 